\title{
Morality of Informality: Tax Morale in the Serbian Business Sector - an Empirical Investigation ${ }^{2}$
}

\author{
Article history: \\ Received: 28 December 2018 \\ Sent for revision: 15 January 2019 \\ Received in revised form: 18 March 2019 \\ Accepted: 19 March 2019 \\ Available online: 1 April 2019
}

\begin{abstract}
The paper examines the attitudes and perceptions of Serbian businesses regarding justifiability of tax evasion and assess factors that make tax evasion morally acceptable. Using survey of 1,049 businesses in Serbia, the paper finds strong evidence that the negative evaluation of the tax authorities is associated with lower tax morality. Both the ordered logit model (OLM) and the partial proportional odds model (PPOM) as a desirable alternative to OLM were used in the analysis. The perception of the risk of being caught and the overall tolerance of tax evasion are also associated with lower tax morality of businesses (business owners and managers). Results suggest that in the next period it would be important for the Serbian tax authorities to improve how businesses perceive their activities and significantly improve their perception and relationship with business taxpayers.
\end{abstract}

Keywords: tax morality, business owners, informal economy, tax compliance.

\section{Moralnost neformalnog poslovanja: Poreski moral sektora preduzeća u Srbiji - empirijska analiza}

Apstrakt: Rad razmatra stavove i percepcije poslovnog sektora u Republici Srbiji u pogledu opravdanosti izbegavanja plaćanja poreza $i$ istražuje okolnosti u kojima se poreska evazija smatra prihvatljivom. Na osnovu ankete 1.049

\footnotetext{
${ }^{1}$ Faculty of Law, University of Belgrade, bradulovic@ius.bg.ac.rs

${ }^{2}$ This paper is a result of the University of Belgrade Faculty of Law project titled "Serbia's Identity Transformation".
} 
Radulović B.: Morality of Informality: Tax Morale in the Serbian Business Sector - an...

preduzeća i preduzetnika dobijamo robusne rezultate u pogledu uticaja stavova o kompetencijama i radu poreske uprave na poreski moral. Rad analizira podatke koristeći logit model poređanog izbora i parcijalni proporcionalni model izgleda kao bolji pristup. Percepcija rizika otkrivanja neplaćanja poreza, kao i mišljenja o opštoj tolerantnosti poreske evazije u društvu takođe su povezani sa nižim poreskim moralom vlasnika i direktora preduzeća i preduzetnika. Rezultati ukazuju sa je u predstojećem periodu za poboljšanje usklađenosti sa poreskim propisima u Srbiji od izuzetnog značaja da poreske vlasti poboljšaju percepciju i odnos sa poreskim obveznicima sektora preduzeća.

Ključne reči: poreski moral, vlasnici preduzeća, siva ekonomija, poreska usklađenost

\section{Introduction}

Based on the economic model of tax evasion (Allingham \& Sandmo, 1972) individuals choose the level of tax compliance by comparing the benefits of tax evasion and costs, i.e. the perceived probability of detection and punishment. While deterrence matters, one of the main implications in empirical literature is that tax compliance is significantly higher compared to the level that can be explained by the standard economic model (Torgler, 2007; Kirchler, 2007; Dell'Anno, 2009). Consequently, there is an increasing body of research arguing that it is not possible to fully understand tax compliance decisions without considering ethical dimensions, and that recognizes tax morality as the key determinant to explain the levels of tax compliance (Alm, 2018; Alm \& Torgler, 2011).

Tax morality is most often defined as an intrinsic motivation for tax compliance (Luttmer \& Singhal, 2014). Still, in theoretical and empirical literature on tax compliance, tax morality (or tax morale, as it is frequently referred to in literature) was commonly examined without referring to the specific factors that affects tax morality (Feld \& Frey, 2002). More recently, tax morality has become one of the key issues in the empirical research on tax compliance (Lago-Peñas \& Lago-Peñas, 2010), and has been related to the various environmental factors that the taxpayer takes into consideration when reaching his tax compliance decisions (Filippin, Fiorio, \& Viviano, 2013). However, most of the literature on tax morality was devoted to individuals, and so far, only a few studies have focused on firms (Alm \& McClellan, 2012; Mickiewicz et al., 2017).

In recent years, tax compliance and the shadow economy in Serbia have attracted increasing interest from policymakers and academics. This is not surprising as the informal sector plays a significant role in Serbia's economy. 
Radulović B.: Morality of Informality: Tax Morale in the Serbian Business Sector - an...

Researchers have begun to emphasize the importance of policies that affect the intrinsic factors in tax compliance decisions in Serbia (Ranđelović, 2017), while others found that there is a significant negative correlation between the size of informal sector and tax morality (Krstić \& Radulović, 2015, 2017). Hence, in the context of ongoing tax reforms in Serbia, it is expected that the issue of tax morality will be increasingly important.

Following empirical literature (Alm \& McClellan, 2012; Mickiewicz et al., 2017; Bird et al., 2008; Torgler et al., 2007; Lago-Peñas \& Lago-Peñas, 2010) the article examines determinants that shape tax morality of businesses (owners and managers) in Serbia. The paper exploits novel data set for more than 1,000 businesses (firms and entrepreneurs) collected in 2017 that provide information about the attitudes towards paying taxes and informal economy, perceptions towards the tax system and experiences with tax authorities.

The aim of this study is to analyse determinants of tax morality in the business sector in Serbia. This aim is relevant not only for tax policy but has wideranging implications both for business sector and tax authorities. On the one hand businesses have substantially more opportunities to evade taxes than individuals. Also, the significance of withholding taxes in Serbian tax system makes the tax morality of business owners and managers even more important. On the other hand, given that deterrence is far from being efficient, better understanding of tax morality may contribute to the reduction of tax evasion by suggesting new compliance mechanisms.

By examining the tax morality of Serbia's business sector, this paper makes several contributions. Firstly, the paper presents the initial results on what affects tax morality in Serbia. Secondly, it adds to the existing empirical literature on the determinants of tax morality in transition countries. Thirdly, by empirically examining potential factors that affect tax morality of business owners and managers, the paper contributes to the relatively scarce literature that is focusing on businesses.

The paper is organized as follows: Section 2 provides a literature review and a general framework for examining the determinants of tax morality; Section 3 describes the empirical methodology and data; Section 4 presents the results; and the final section provides tentative conclusions and potential suggestions for further research.

\section{Determinants of tax morality}

As stated in the introduction, literature mostly addresses the tax morality of individuals. These studies use data sets such as the World Values Survey (WVS), the European Values Survey (EVS), etc. These surveys directly ask 
Radulović B.: Morality of Informality: Tax Morale in the Serbian Business Sector - an...

individuals about their attitudes towards tax evasion. For example, the WVS asks respondents to rate the justifiability of "cheating on taxes if one has a chance." Based on these surveys, empirical literature on tax morality of individuals either examines either a single country (Torgler, 2005; MartinezVazquez \& Torgler, 2009; Cyan et al., 2014), two countries (Torgler et al., 2008; Bilgin, 2014), or a large data set covering a number of countries (Alm \& Torgler, 2006; Heinemann, 2011; Torgler, 2012; Lago-Peñas \& Lago-Peñas, 2010).

In literature, besides pure intrinsic incentive (e.g. feeling of pride or selfesteem), tax morality is associated with a set of underlying motivations for tax compliance. Luttmer \& Singhal (2014) identifies other elements, which include reciprocity (subject's view on state-run institutions based on the quality and the quantity of public goods they provide, or observations about the impartiality of the tax system), peer-related and general social influences (subject's perception about the compliance of others), long-standing cultural factors, and information imperfections (subject may have a wrong perception about the probability of detection and punishment). Alternative classification of determinants is provided by Pope \& Mohdali (2011) who divide factors that can affect individual tax morality in two groups. The first group is related to the external environment that influences attitudes of businesses, i.e. government (tax administration, legislation) and society (culture, traditions). The second group is related to individuals' attitudes i.e. moral and religious beliefs. Similarly, Lago-Peñas \& Lago-Peñas (2010) differentiate between individualand contextual-level variables. Based on the review of literature they observed four types of variables: (1) socio-demographic characteristics, (2) political and social attitudes, (3) fiscal parameters including deterrence, and (4) contextual level variables (including regional characteristics, culture, language fragmentation, etc.). However, in some cases this distinction is rather arbitrary, e.g. Feld \& Frey (2007) state that tolerance and bribery provide disincentives to comply because of perceived unfairness.

To analyse the tax morality of businesses, Alm \& McClellan (2012) uses data from the Business Environment and Enterprise Performance Survey of 57,000 businesses from 79 countries. However, as these surveys do not have a specific question regarding the morality of cheating on taxes, authors approximated tax morality by using "taxes as obstacle" and obtaining tax morality as a residual error term after controlling for other effects. Mickiewicz et al. (2017), similar to this paper, uses a survey of businesses (owners and managers) conducted in Latvia in 2010. It examines how various institutional factors affect tax morality of business owners and managers. More specifically they distinguish three institutional aspects: (1) normative, (2) cognitive, and (3) regulatory. The normative aspect examines the effect of the perceived legitimacy and the performance of the government and the tax authority on tax morality. The cultural-cognitive aspect examines how the owner's and 
Radulović B.: Morality of Informality: Tax Morale in the Serbian Business Sector - an...

manager's identification with the national policy affects tax morality. Finally, the regulatory aspect implies the calculation of the costs and benefits of noncompliance compared to paying tax. The finding was that the tax morality of business owners and managers in Latvia is affected by all three institutional aspects.

Following relevant literature, the modelling approach included not only variables describing the characteristics of a respondent (firm or sole proprietor), but also variables that reflect attitudes, perceptions and other contextual factors to help explain tax morality. More specifically, several groups of factors were used to examine determinants that affect tax morality of businesses in Serbia. For each group of factors, a relevant hypothesis was developed to be tested in the empirical model.

First, businesses' perception of the tax authority may affect tax morality. The views of business owners and entrepreneurs are based on how businesses are approached and treated by the tax authorities (inspection). Fair and predictable treatment improves the respect and reputation of the tax authorities and thus leads to compliance. Contrarily, unfair and unpredictable treatment tends to diminish intrinsic incentive to be compliant (Feld \& Frey, 2002; Torgler, 2007). Explicit questions were used for business' perception of tax administration performance and whether the business has any objections to the performance of the tax administration (if the business stated that the tax administration either displayed inconsistency in implementing regulations, or showed incompetence, or created unnecessary administrative burdens, or instigates corruptive behaviour).

Hypothesis 1: Businesses that disapprove of the tax authorities' actions and the treatment of tax payers (negatively perceive tax authorities) will judge underreporting to be less unacceptable (unethical) than taxpayers who have a favourable view.

Second, tax morality may depend on businesses' perception of the prevalence of evasive behaviour in a society or in a particular sector. If businesses believe that many businesses evade taxes, this could crowd out intrinsic motivation to comply with taxes. Compliant businesses might get annoyed, which decreases the ethical costs of non-compliance (Luttmer \& Singhal, 2014). To proxy for this "peer effect", the businesses' estimate of the percentage of turnover that is not reported for tax purposes was used, as well as the estimate of the percentage of unregistered businesses. Two scales were used testing Hypothesis $2 \mathrm{a}$ and $2 \mathrm{~b}$, constructed based on respondent assessments of (1) the percentage of turnover for which taxes are not paid, and (2) the percentage of businesses that are unregistered. Both assessments are related to the sector in which the respondents operate. 
Radulović B.: Morality of Informality: Tax Morale in the Serbian Business Sector - an...

Hypothesis 2a: Businesses that notice many other registered businesses evading taxes have lower tax morality i.e. they will judge informal activities as being less unethical.

Hypothesis 2b: Businesses that notice that many others do business completely informally have lower tax morality.

Similarly, prevalent corruption increases the expectations of bribe offers and significantly harms tax morality and increases tax evasion (Jahnke \& Weisser, 2018; Torgler, 2006). Views of businesses on the prevalence of tax related bribery (very common $=4$, common $=3$, some occurrences $=2$, no occurrences $=1$ ) were used to assess the impact of corruption on tax morality.

Hypothesis 2c: Businesses that state that the use of bribery to evade taxes is common have lower tax morality.

Lastly, the perception that tax evasion is a practice that is tolerated in Serbia may be a significant detriment to tax morality. The views of business owners and managers on the extent to which tax evasion practices are tolerated in Serbia were used to assess the impact of general tolerance on tax morality.

Hypothesis 2d: Businesses that perceive that tax evasion is a practice that is tolerated will judge informal activities to be less unethical.

Third, businesses' perception of the tax system as fair and equitable also affects tax morality. Businesses are incentivized to comply if they believe that there is a fair and equitable exchange between public goods provided by the state and the paid tax (Torgler, 2003; Torgler, 2005; Torgler \& Schneider, 2007). Two dummy variables were used to proxy if businesses stated that tax evasion is mostly affected by 1 ) inefficient and inequitable tax spending or 2) the existence of privileged companies.

Hypothesis 3a: Businesses that see the tax system as unfair and unequitable will judge informal activities to be less unethical.

Furthermore, literature observes that higher tax rates (tax burden) negatively affects tax morality (Bird et al., 2008). Thus, businesses' perceptions of the tax burden were used as an additional predictor in the model.

Hypothesis 3b: Businesses that believe that the tax burden is high have lower tax morality i.e. will judge informal activities to be less unethical.

Fourth, complexity may result both in unintentional and intentional noncompliance. As argued in Luttmer and Singhal (2014) "information imperfections and decision-making biases are not always considered in the context of tax morale, but they clearly represent deviations from a fully rational model of tax compliance". Hence, complexity costs may affect compliance 
Radulović B.: Morality of Informality: Tax Morale in the Serbian Business Sector - an...

decisions, or, in other words, they reduce the moral costs (e.g. feeling of guilt, compunction) of evading taxes (Torgler, 2003). Complexity was proxied by using dummy variables for companies that stated that complicated tax laws and rules are among the top three obstacles to doing business in Serbia.

Hypothesis 4: Businesses that state that complicated tax procedures and unclear tax laws represent a key issue affecting their operations have lower tax morality.

Fifth, businesses' trust in the government (public officials) affects their willingness to comply. If businesses find that the government is trustworthy, they will be more willing to comply. The following question was used as a proxy for general trust in the government: Do you believe that the state is decisive in the fight against the informal economy?

Hypothesis 5: Businesses with low trust in government intentions to curb informal economy (tax evasion) will judge informal activities to be less unethical than taxpayers with high trust in government.

Sixth, recent studies (Blanthorne \& Kaplan, 2008) suggests that deterrence factors may affect tax morality, i.e. tax morality could be affected by a selfserving bias, whereby people adjust their norms/attitudes according to their self-interest. Similar findings obtained in a real effort laboratory experiment shows that individuals with an evasion opportunity judge tax evasion as less unethical (Blaufus et al., 2015). Hence, following Mickiewicz et al. (2017) an additional hypothesis is formulated:

Hypothesis 6: Businesses that perceive a lower likelihood of being caught evading tax will judge informal activities to be less unethical.

The variable was developed from the following statement: Evaluate the probability that a company operating informally would be discovered? (between $0 \%=1$ and $100 \%=11$ ).

Controls are included for business performance in the previous year, whether the business is incorporated, whether business is a VAT payer, and also for regional and sector fixed effects. Business performance can be another important factor for tax morality. However, the relationship between business performance and tax morality is not clear. It might be argued that loss-making businesses will judge informal activities to be less unethical compared to successful businesses. Hence, a parallel could be drawn with literature on the tax morality of individuals, which shows that those who report having economic problems are more likely to justify tax evasion. In our case this might be explained by the fact that loss-makers have to evade paying taxes to survive. On the other hand, loss-making businesses may blame tax evaders for not being able to have better business results. Also used is the number of 
Radulović B.: Morality of Informality: Tax Morale in the Serbian Business Sector - an...

employees, as a proxy for size. However, as this variable did not significantly change the findings, the paper did not report these results.

\section{Data and Methodology}

The survey was conducted in 2017 , on a single-stage stratified sample of registered businesses. Companies and/or small privately-owned businesses (sole proprietors) not formally incorporated and registered were not included (Krstić, 2015; Krstić \& Radulović, 2018). A total of 1,049 businesses were surveyed $(61 \%$ of all respondents were owners, $25 \%$ managing directors and $13 \%$ chief financial officers). The results are obtained using weights to make the sample representative at the national level and by stratum (region, sector and size).

Literature suggests attitudes towards the justifiability of tax evasion as an adequate proxy for tax morality (Alm \& Torgler, 2011). Surveys usually ask individuals (not businesses) about attitudes towards tax evasion (Onu, 2016). For example, the WVS asked respondents to rate the justifiability of "cheating on taxes if you have a chance." While direct information on a firm's "tax morality" is not available, this article specifies tax morality as a dependent variable by using the following question "What is your attitude to the justification of informal business activities?" It is our belief that this question adequately captures tax morality since for the purpose of the survey informal business is defined as "actions taken by individuals and firms to reduce their legally due tax obligations, by underreporting incomes or sales to evade consumption and profit taxes and 'envelope wages' to evade payroll tax and/or social security contributions” (Krstić, 2015; Krstić \& Radulović, 2018).

Table 1 Frequencies and cross-tabulation of tax morale measure (weighted)

\begin{tabular}{|l|r|r|}
\hline Informal activity in Serbia is justifiable & \multicolumn{1}{|c|}{ Freq. } & \multicolumn{1}{c|}{ Percent } \\
\hline Strongly disagree (not justifiable at all) & 580.6 & 56.7 \\
\hline Mainly disagree (mainly not justifiable) & 247.8 & 24.2 \\
\hline Neutral (both is and isn't justifiable) & 159.0 & 15.5 \\
\hline Mainly agree (mainly justifiable) & 33.8 & 3.3 \\
\hline Strongly Agree (entirely justifiable) & 2.8 & 0.3 \\
\hline Total & 1,024 & 100 \\
\hline
\end{tabular}

Source: Author research

The morality indicator has been represented by a 5-point Likert scale. However, as those who strongly justify tax evasion represent only $0.3 \%$ of the sample, the ordinal variable is collapsed into four categories. Alternatively, the dependent variable could be dichotomized, and binary logistic regression applied, but information would be lost, and this could substantively alter the conclusions. For the sake of clarity, the reverse score is used - the higher the 
Radulović B.: Morality of Informality: Tax Morale in the Serbian Business Sector - an...

index value, the higher the tax morality is. Hence, variable Tax Morality equals 1 if the respondent strongly agrees that "informal activity in Serbia is justifiable" and 4 if they strongly or mainly disagree with the previous statement. Tax morality is estimated using sampling weights to ensure that the results are representative (Table 1).

Detailed explanations of the variables used in the regression analysis are presented in Table 2.

Table 2 Description of variables in the regression analysis (unweighted)

\begin{tabular}{|l|r|r|r|r|r|}
\hline \multicolumn{1}{|c|}{ Variable } & \multicolumn{1}{c|}{ Obs } & \multicolumn{1}{c|}{ Mean } & \multicolumn{1}{c|}{ Std. Dev. } & \multicolumn{1}{c|}{ Min } & \multicolumn{1}{c|}{ Max } \\
\hline Morality & 1,024 & 3.4 & 0.9 & 1 & 4 \\
\hline Disapproval of Tax Authority & 880 & 0.4 & 0.5 & 0 & 4 \\
\hline Tolerance & 999 & 2.2 & 0.9 & 1 & 8 \\
\hline Unreported Turnover & 899 & 2.8 & 1.7 & 1 & 1 \\
\hline Unregistered & 969 & 2.6 & 1.5 & 1 & 8 \\
\hline Detection Probability & 977 & 6.1 & 2.7 & 1 & 11 \\
\hline Bribe Prevalence & 794 & 2.4 & 0.7 & 1 & 4 \\
\hline Trust in Government & 990 & 2.9 & 0.8 & 1 & 4 \\
\hline VAT & 1,047 & 0.6 & 0.5 & 0 & 1 \\
\hline Complicated Tax Procedures & 1,039 & 0.1 & 0.3 & 0 & 1 \\
\hline High Tax Burden & 1,039 & 0.4 & 0.5 & 0 & 1 \\
\hline Sole Proprietor & 1,049 & 0.5 & 0.5 & 0 & 1 \\
\hline Loss Making & 1,042 & 0.1 & 0.3 & 0 & 1 \\
\hline Foreign Ownership & 1,049 & 0.0 & 0.2 & 0 & 1 \\
\hline Belgrade & 1,049 & 0.3 & 0.5 & 0 & 1 \\
\hline Vojvodina & 1,049 & 0.3 & 0.4 & 0 & 1 \\
\hline In(Age) & 1,041 & 2.5 & 0.7 & 0 & 4.6 \\
\hline
\end{tabular}

Source: Author research

The limitations of the data are mainly related to the several variables in the model that may not capture individual-level effects adequately and to the possible bias in the survey responses, i.e. respondents may be more likely to answer in a socially-desirable way (Beck \& Ajzen, 1991). As stated in Torgler (2005, p.141), "it can be argued that a tax payer who has incurred in some illegal behaviour in the past will tend to excuse this kind of behaviour declaring a high tax morale." However, it is our opinion belief that it is reasonable to assume that attitudes and perceptions are relevant in explaining why businesses act in certain ways, i.e. whether they will evade or not.

Given that tax morality represents an ordered categorical variable, ordered probit or ordered logit represent appropriate econometric methods (Long, 1997; Long and Freese, 2014). For the empirical investigation, we first employ a standard ordered logit model (OLM). The OLM can be expressed as follows: 
Radulović B.: Morality of Informality: Tax Morale in the Serbian Business Sector - an...

$\mathrm{P}\left(Y_{i}>j\right)=\mathrm{g}(X \beta)=\frac{\exp \left(\alpha_{j}+X_{i} \beta\right)}{1+\left\{\exp \left(\alpha_{j}+X_{i} \beta\right)\right\}}, j=1,2, \ldots, C-1$

where $C$ represents the number of outcomes of the dependent variable.

The OLM imposes proportional odds assumption on the data, i.e. it assumes that the coefficients that describe the relationship between various categories of the response variable will remain the same (Williams, 2016). Hence, the OLM is a restrictive but parsimonious model. Furthermore, if the proportional odds (parallel lines) assumption is violated, estimating an OLM will lead to inconsistent results.

To relax the proportional odds assumption, one can use a generalized ordered logit model. In the generalized unconstrained model, each independent variable has a different impact on various categories of the ordinal outcome variable. The expressions for the proportional odds and generalized model are the same, except that in the proportional odds model the $\beta$ 's are the same for all values of $j$ (Williams, 2006).

$\mathrm{P}\left(Y_{i}>j\right)=\mathrm{g}\left(X \beta_{j}\right)=\frac{\exp \left(\alpha_{j}+X_{i} \beta_{j}\right)}{1+\left\{\exp \left(\alpha_{j}+X_{i} \beta_{j}\right)\right\}}, j=1,2, \ldots, c-1$

The problem with this approach is that it relaxes all variables from the proportional odds assumption even though the assumption may be violated by one or several of them (Williams, 2006). Hence, an unconstrained generalized model; while it is rather flexible, it has more parameters and it is not parsimonious.

The third option, the partial proportional odds model (PPOM), relaxes the proportional odds assumption only for those variables where this assumption is violated. In the PPOM, some of the $\beta$ coefficients will be the same for all values of $j$, while others can differ. The PPOM also allows a variable to gain or lose statistical significance and/or change coefficient sign for various values of the dependent variable. On the one hand, PPOM is somewhat more difficult to interpret than the OLM. On the other hand, PPOM provides additional insights which would not be observed in case of the OLM. The PPOM can be expressed as follows. In our example, the $\beta$ 's for all except one variable are the same for all values of $j$ but the $\beta$ 's for $X 3$ differ. 
Radulović B.: Morality of Informality: Tax Morale in the Serbian Business Sector - an...

$$
\mathrm{P}\left(Y_{i}>j\right)=\frac{\exp \left(a_{j} X 1_{i} \beta 1+X 2_{i} \beta 2+X 3_{i} \beta a_{j}\right)}{\left.1+\left[\exp \left(\alpha_{j} X 1_{i} \beta 1+X 2_{i} \beta 2+X 3_{i} \beta 3_{j}\right)+X_{i} \beta_{j}\right)\right\}}, j=1,2, \ldots, C-1
$$

In our study, the dependent variable has four categories, so $\mathrm{C}=4$, hence for $\mathrm{J}$ $=1$ category 1 (completely or mainly justified) is compared to categories 2, 3, and 4 ; for $\mathrm{J}=2$ the comparison is between categories 1 and 2 (informality is completely or mainly justifiable and neutral) and categories 3 and 4; and for $\mathrm{J}$ $=3$, we compare categories 1,2 , and 3 , and category 4 (completely unjustifiable).

The test devised by Brant (1990) is commonly used to test the proportional odds assumption. However, the Brant test is not appropriate for our study as survey weights were use. Wald tests were used to test the proportional odds assumption. More specifically, results are obtained using Williams (2006) Stata command gologit2, which allows the estimation of the PPOM. This command allows identification of any independent variable that violates the proportional odds assumption. The autofit option was used, which only relaxes the proportional odds constraint for those variables where it is violated. The Stata command calculates Wald tests for each variable, in order to examine whether the variable meets the proportional odds assumption. In the event that the result of the Wald test is statistically insignificant, the variable will be constrained to have equal coefficient across equations. Finally, the autofit option was set to equal 0.025 of significance, which is consistent with Williams (2006) suggestion that the default level of significance (0.05) may not be sufficiently strict in cases when multiple variables are being tested.

\section{Results}

Table 3 shows the predictors in our models. Table first presents the results based on the standard OLM to provide for point of reference for the PPOM. Table 3 presents results both as coefficients and as the proportional odds ratios. The effects of the constrained variables in the PPOM model can be understood similarly to those in the OLM. The OLM model also presents the cut points for the adjacent levels of the response variable. By allowing a variable to vary across the values of the dependent variable, the PPOM requires somewhat different presentation. As the dependent variable (tax morality contains four ordered categories) there are three levels simultaneously examined in the model. Level one presented as 1 vs. 2, 3 and 4 corresponds to the comparison between the category 1 and all of the other ordered categories of tax morality. Three levels are presented separately within the table for two variables that violated the proportional odds 
Radulović B.: Morality of Informality: Tax Morale in the Serbian Business Sector - an...

assumption. Only one set of estimates is reported for other variables that did not violate the proportional odds assumption.

Table 3. Determinants of tax morale

\begin{tabular}{|c|c|c|c|c|c|c|c|}
\hline & $\mathrm{H}$ & & LM & & & POM & \\
\hline & & Coeff. & or & z stat & Coeff. & or & z stat \\
\hline Disapproval of Tax Authority & 1 & $-0.680^{\star \star *}$ & 0.507 & $(-2.89)$ & $-0.732^{\star \star \star}$ & 0.481 & $(-3.16)$ \\
\hline Unreported Turnover & $2 \mathrm{a}$ & 0.121 & 1.128 & $(1.24)$ & 0.094 & 1.098 & $(1.06)$ \\
\hline Unregistered presence & $2 b$ & $-0.182^{*}$ & 0.834 & $(-1.79)$ & & & \\
\hline (1 vs $2,3,4)$ & & & & & $-0.431^{* * *}$ & 0.650 & $(-3.23)$ \\
\hline$(1,2$ vs 3,4$)$ & & & & & $-0.307^{\star * *}$ & 0.735 & $(-3.03)$ \\
\hline$(1,2,3$ vs 4$)$ & & & & & -0.0776 & 0.925 & -0.39 \\
\hline Bribe Prevalence & $2 c$ & -0.123 & 0.884 & $(-0.85)$ & -0.135 & 0.873 & $(-0.91)$ \\
\hline Tolerance & $2 d$ & $-0.466^{\star * *}$ & 0.628 & $(-3.61)$ & $-0.435^{\star \star *}$ & 0.647 & $(-3.32)$ \\
\hline High Tax Burden & $3 b$ & -0.121 & 0.886 & $(-0.60)$ & -0.114 & 0.892 & $(-0.56)$ \\
\hline Complicated Tax Procedures & 4 & -0.285 & 0.752 & $(-0.82)$ & -0.338 & 0.713 & $(-1.01)$ \\
\hline Trust in Government & 5 & -0.0911 & 0.913 & $(-0.64)$ & -0.130 & 0.878 & $(-0.92)$ \\
\hline Detection Probability & 6 & $-0.065^{*}$ & 0.937 & $(-1.81)$ & $-0.064^{*}$ & 0.938 & $(-1.78)$ \\
\hline VAT & & 0.0438 & 1.045 & $(0.20)$ & 0.034 & 1.035 & $(0.15)$ \\
\hline Sole Proprietor & & -0.263 & 0.769 & $(-1.31)$ & -0.307 & 0.735 & $(-1.45)$ \\
\hline $\ln ($ age $)$ & & 0.277 & 1.319 & $(1.55)$ & 0.248 & 1.282 & $(1.38)$ \\
\hline Belgrade & & $-1.285^{\star * *}$ & 0.277 & $(-5.31)$ & & & \\
\hline (1 vs $2,3,4)$ & & & & & 0.134 & 1.144 & $(0.20)$ \\
\hline$(1,2$ vs 3,4$)$ & & & & & $-0.812^{\star * *}$ & 0.444 & $(-1.39)$ \\
\hline$(1,2,3$ vs 4$)$ & & & & & $-1.601^{* * *}$ & 0.200 & $(-5.88)$ \\
\hline Vojvodina $\quad$ Central Serbia & & $-0.577^{*}$ & 0.562 & $(-1.94)$ & $-0.528^{*}$ & 0.590 & $(-1.89)$ \\
\hline Foreign Ownership & & -0.451 & 0.637 & $(-1.08)$ & -0.530 & 0.588 & $(-1.10)$ \\
\hline Loss Making & & $0.785^{\star *}$ & 2.191 & $(2.17)$ & $0.859^{* *}$ & 2.361 & (2.32) \\
\hline Industry & & -0.173 & 0.841 & $(-0.59)$ & -0.133 & 0.876 & $(-0.45)$ \\
\hline Construction & & 0.235 & 1.264 & $(0.58)$ & 0.207 & 1.230 & $(0.50)$ \\
\hline Trade & & -0.167 & 0.846 & $(-0.64)$ & -0.172 & 0.842 & $(-0.64)$ \\
\hline Transport & & $-0.966^{\star \star \star}$ & 0.381 & $(-2.59)$ & $-0.992^{\star \star *}$ & 0.371 & $(-2.73)$ \\
\hline Catering & & -0.289 & 0.749 & $(-0.56)$ & -0.301 & 0.740 & $(-0.58)$ \\
\hline Other sectors & & $6111^{\star \star \star *}$ & & & & & \\
\hline cut1 & & $-6.414^{\star \star \star}$ & & & & & \\
\hline $\begin{array}{l}\text { cut2 } \\
\text { cut3 }\end{array}$ & & $\begin{array}{l}-4.041 \\
-2.933^{* * *}\end{array}$ & & & & & \\
\hline Constant (1 vs $2,3,4$ ) & & & & & $7.161^{* * *}$ & & $(6.77)$ \\
\hline Constant $(1,2$ vs 3,4$)$ & & & & & $4.844^{\star * *}$ & & (4.84) \\
\hline Constant $(1,2,3$ vs 4$)$ & & & & & $2.966^{\star \star *}$ & & (3.13) \\
\hline $\mathrm{N}$ & & & & 571 & & & 571 \\
\hline Wald chi2 & & & & 85.07 & & & 109.32 \\
\hline Pseudo R2 (McFadden) & & & & 0.090 & & & 0.121 \\
\hline AIC & & & & 1148.78 & & & 1129.50 \\
\hline $\mathrm{BIC}$ & & & & 1253.12 & & & 1251.23 \\
\hline
\end{tabular}

${ }^{*} \mathrm{p}<0.1,{ }^{\star *} \mathrm{p}<0.05,{ }^{\star * \star} \mathrm{p}<0.01$, robust standard errors in parentheses. Results adjusted for sampling design Two-tailed test. For variables in violation of the parallel lines assumption results present comparison between outcomes.

\section{Source: Author research}

Negative attitudes towards the tax authority significantly decrease tax morality. Businesses that state that tax authorities are inconsistent or unpredictable in application of tax rules, or that inspections are time consuming, corrupt or have other issues with the application of tax rules, are much more likely to justify evasion at least to some extent. The odds of higher tax morality are 0.51 times lower (0.48 in PPOM) in cases where the 
Radulović B.: Morality of Informality: Tax Morale in the Serbian Business Sector - an...

businesses disapprove of the tax authority. The obtained results are rather robust, as respondent disapproval of the actions of tax authorities and the treatment of tax payers has a negative effect on tax morality and the result is statistically significant at $1 \%$ across different specifications supporting Hypothesis 1.

While the results do not provide support Hypothesis $2 a$ regarding the registered businesses "peer effect", having a higher level of perceived competition from informal business reduces tax morality by about $16.6 \%$, thus supporting Hypothesis 2b. Additional implications of the second model (PPOM) on Hypothesis $2 \mathrm{~b}$ will be discussed later. Similar results are obtained for the perceived tolerance of tax evasion. A one-unit increase in perceived tolerance would result in the ordered log-odds of 0.47 (0.44 in PPOM) of having a higher level of morality while the other variables in the model are held constant, providing support for Hypothesis $2 \mathrm{~d}$. The detection probability coefficient is of the expected negative sign and statistically significant at the 0.1 level, for both the OLM and the PPOM model. That is, tax morality is lower for businesses that perceive higher probability of being caught. The perception of bribe prevalence has an expected sign, but it is not significant, failing to support Hypothesis 2c. Similarly, the odds ratio for high tax burden, complicated tax procedures and trust in government is not statistically significant for tax morality, providing no support for hypotheses 3, 4 and 5 .

Neither complexity nor equity or perception of high tax burden have a statistically significant effect on tax morality. The inclusion of a variable for perceived equity does not contribute to the model. As the Bayesian Information Criterion (BIC) provides strong support for the model without perception of fairness, the final model excludes this variable and do not report results.

To present the effects of the most significant independent variables on tax morality, Figure 1 plots the predicted probabilities of each category of tax morality, while holding all the other independent variables fixed at their mean values (Greene \& Hensher, 2010; Williams, 2012). Predicted probabilities are obtained from estimates of the OLM model. Figure 1 shows how the probability of an average business owner's/manager's morality outcome varies with the change of an independent variable. The horizontal axis shows the value of the morality variable at which the predicted probability of the tax morality outcome is obtained. The vertical axis shows the values of the predicted probabilities for each tax morality outcome. Each panel has four lines plotting the relationship between tax morality and the relevant independent variable.

Panel A (Figure 1) plots the predicted probabilities for each outcome and the perceived tolerance as an independent variable. As perceived tolerance 
Radulović B.: Morality of Informality: Tax Morale in the Serbian Business Sector - an...

increases, the probability of a respondent justifying informal activity increases. The line in Panel A representing the predicted probability that an average business thinks tax evasion is completely unjustifiable, when perceived tolerance is very low ( $x$ axis $=1$ ), shows that the predicted probability of thinking tax evasion is completely unjustifiable is 0.69 . As perception of the prevalence of tax evasion tolerance increases, the probability that an average business believes that tax evasion is completely unjustifiable decreases. In other words, when perceived tolerance is high $(x=4)$ the predicted probability that an individual will not judge informal activities to be completely unethical drops to 0.40 . Panel B plots the predicted probabilities for each morality outcome and businesses' expectation of the detection, holding all other independent variables constant. In Panel B - as beliefs about the probability of detection increase from " $0 \%$ " (1) to " $100 \%$ " (11), the predicted probability of "completely unjustifiable" falls from 0.63 to 0.49 . Similar trends are seen in Panel C, which shows the relationship between the views on the share of unregistered businesses and tax morality.

Figure 1. Predicted probabilities for the 4-category version of tax morale
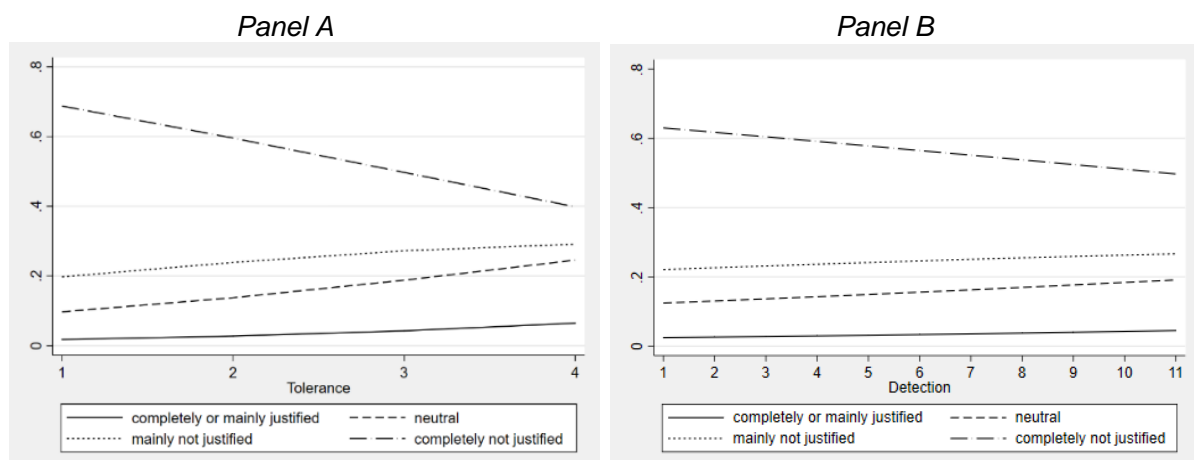

Panel C

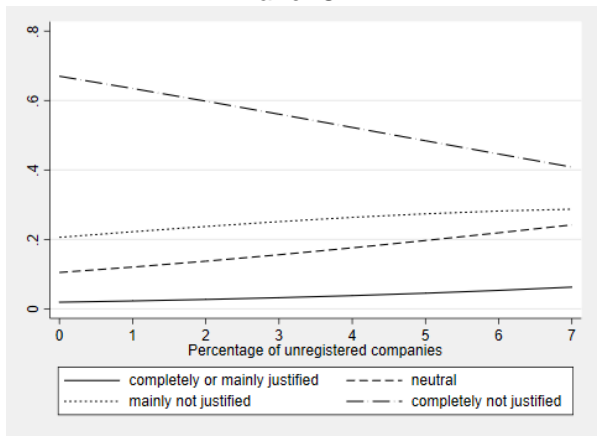

Source: Author research 
Radulović B.: Morality of Informality: Tax Morale in the Serbian Business Sector - an...

With respect to control variables, performance coefficients and location of the business are statistically significant. Results support an alternative hypothesis that loss-making businesses report higher tax morality. The odds of higher tax morality are 2.19 times higher (2.26 in PPOM) in cases where businesses report losses. Hence, firms that face financial difficulties were less prone to evading taxes compared to those with fewer financial constraints.

Two controls - respondents that are within the VAT system and sole proprietors - failed to meet a required level of statistical significance. Sectoral dummies are not statistically significant except for the transport sector, which is significant and negative in both the OLM and the PPOM models. The location of the business is important, and tax morality is, on average, significantly lower in Belgrade than in Central Serbia. This is consistent with literature, which reports that individuals living in rich regions are less prone to tax compliance. A possible additional explanation is that citizens and businesses in Central Serbia believe that they have an obligation to support their local community.

For two unconstrained variables, Unregistered presence and Belgrade, examining the pattern of coefficients reveals additional insights that would have been neglected had only the OLM model been presented. The PPOM results for two variables can be interpreted in the following manner: negative coefficients indicate that higher values of the Unregistered presence variable increase the probability of businesses having lower tax morality. The results report that the effect of pervasive unregistered informality perception is more extreme at lower levels of morality. For Belgrade, the pattern shows that Belgrade-based businesses are less likely to report strong support for evasion (the positive coefficient in the first row), but Belgrade-based businesses are much more likely to justify at least some level of informality (the negative coefficients in the other two rows).

\section{Conclusions}

The results provide first evidence of the factors that affect the tax morality in Serbia's business sector. While factors related to individuals should have similar effects on firms (Alm and McCllelan, 2012), the results suggest that business owners and managers are more influenced by specific tax administration and less by general government issues. Strong evidence has been found that the disapproval of the actions of tax authorities and the treatment of tax payers is associated with lower tax morality. However, this is not the case for the general trust in government. A possible explanation is that satisfaction with the government and with public services is not as an important contributor to tax morality as in the case of individuals. Hence, in 
Radulović B.: Morality of Informality: Tax Morale in the Serbian Business Sector - an...

the next period it would be important for the tax authorities to improve how businesses perceive their activities and improve legitimacy and their relationships with business taxpayers.

Evidence was also found that tax morality is affected by perceived tolerance, and that tax morality in Serbia may be affected by a self-serving bias. This suggests that tax morality is partly eroded because the lack of enforcement efforts, hence signalling to business owners and managers that compliance is only somewhat important.

However, there are some obvious limitations of the study. First, the data set does not contain relevant information on sex, age, nationality and level of education of business owners and managers, which could provide additional insights. This does not allow for the examination of how identity-related factors affect tax morality. This requires further investigation, since better understanding of the determinants that affect tax morality is critical both for the tax authorities and businesses.

\section{Acknowledgements}

I thank NALED for providing the data for this study. I am grateful to the participants of the IFA Central and Eastern European Tax Conference for their valuable suggestions.

\section{References}

Allingham, M. G., \& Sandmo, A. (1972). Income tax evasion: a theoretical analysis. Journal of Public Economics 1(3-4), 322-338. https://doi.org/10.1016/00472727(72)90010-2

Alm, J. (2018). What motivates tax compliance? Journal of Economic Surveys. https://doi.org/10.1111/joes.12272

Alm, J., \& McClellan, C. (2012). Tax Morale and Tax Compliance from the Firm's Perspective. Kyklos 65(1), 1-17. https://doi.org/10.1111/j.14676435.2011.00524.X

Alm, J., \& Torgler, B. (2011). Do Ethics Matter? Tax Compliance and Morality. Journal of Business Ethics. 101(4), 635-651. https://doi.org/10.1007/s10551-011-0761-9

Beck, L., \& Ajzen, I. (1991). Predicting dishonest actions using the theory of planned behavior. Journal of Research in Personality, 25(3), 285-301. http://doi.org/10.1016/0092-6566(91)90021-H

Bilgin, C. (2014). Determinants of tax morale in Spain and Turkey: an empirical analysis. European Journal of Government and Economics, 3(1), 60-74.

Bird, R. M., Martinez-Vazquez, J., \& Torgler, B. (2008). Tax Effort in Developing Countries and High Income Countries: The Impact of Corruption, Voice and Accountability. Economic Analysis and Policy, 38(1), 55-71. 
Radulović B.: Morality of Informality: Tax Morale in the Serbian Business Sector - an...

https://doi.org/10.1016/S0313-5926(08)50006-3

Blanthorne, C., \& Kaplan, S. (2008). An egocentric model of the relations among the opportunity to underreport, social norms, ethical beliefs, and underreporting behavior. Accounting, Organizations and Society, 33(7-8), 684-703. https://doi.org/10.1016/j.aos.2008.02.001

Blaufus, K., Braune, M., Hundsdoerfer, J., \& Jacob, M. (2015). Self-serving bias and tax morale. Economics Letters. 131, 91-93 https://doi.org/10.1016/i.econlet.2015.03.041

Brant, R. (1990). Assessing proportionality in the proportional odds model for ordinal logistic regression. Biometrics, 46, 1171-1178.

Cyan, M. R., Koumpias, A. M., \& Martinez-Vazquez, J. (2016). The determinants of tax morale in Pakistan. Journal of Asian Economics. 47, 23-34. https://doi.org/10.1016/j.asieco.2016.09.002

Dell'Anno, R. (2009). Tax evasion, tax morale and policy maker's effectiveness. The $\begin{array}{llll}\text { Journal of } & \text { 38(6), } & \text { 988-997. }\end{array}$ https://doi.org/10.1016/i.socec.2009.06.005

Feld, L. P., \& Frey, B. S. (2002). Trust breeds trust: How taxpayers are treated. Economics of Governance. 3(2), 87-99. https://doi.org/10.1007/s101010100032

Feld, L. P., \& Frey, B. S. (2007). Tax compliance as the result of a psychological tax contract: The role of incentives and responsive regulation. Law and Policy. 29(1), 102-120. https://doi.org/10.1111/j.1467-9930.2007.00248.x

Filippin, A., Fiorio, C. V., \& Viviano, E. (2013). The effect of tax enforcement on tax morale. 32, 320-331. European Journal of Political Economy. https://doi.org/10.1016/j.ejpoleco.2013.09.005

Greene, W. H., \& Hensher, D. A. (2010). Modeling ordered choices: A primer. Modeling Ordered Choices: A Primer. Cambridge University Press. https://doi.org/10.1017/CBO9780511845062

Heinemann, F. (2011). Economic crisis and morale. European Journal of Law and Economics, 32(1), 35-49.

Jahnke, B., \& Weisser, R. A. (2018). How does petty corruption affect tax morale in Sub-Saharan Africa? European Journal of Political Economy. https://doi.org/10.1016/i.ejpoleco.2018.09.003

Kirchler, E. (2007). The Economic Psyhology of Tax Behaviour. Cambridge University Press. https://doi.org/10.1017/CBO9780511628238

Krstić, G. \& Radulović. B. (2015). The Shadow Economy in the Business and Entrepreneurial Sectors. In G. Krstic and F. Schneider (Eds.) Formalizing the Shadow Economy in Serbia, Policy Measures and Growth Effects, 13-19, Springer International Publishing. https://doi.org/10.1007/978-3-319-13437-6 6

Krstić, G. (2015). The Concept of the Survey of Business and Entrepreneurs Operating Informally. In G. Krstić and F. Schneider (Eds.) Formalizing the Shadow Economy in Serbia, Policy Measures and Growth Effects, 13-19, Springer International Publishing. https://doi.org/10.1007/978-3-319-13437-6 3

Krstić, G. \& Radulović. B. (2018). Siva ekonomija u Srbiji 2017 - Procena obima, karakteristike učesnika i determinante. NALED.

Lago-Peñas, I., \& Lago-Peñas, S. (2010). The determinants of tax morale in comparative perspective: Evidence from European countries. European Journal of Political Economy. 26(4), 441-453. https://doi.org/10.1016/j.ejpoleco.2010.06.003 
Radulović B.: Morality of Informality: Tax Morale in the Serbian Business Sector - an...

Long, J. S., (1997). Regression Models for Categorical and Limited Dependent Variables. Advanced Quantitative Techniques in the Social Sciences Number 7. Sage Publications: Thousand Oaks, CA.

Long, J. S., \& Freese, J. (2014). Regression Models for Categorical Dependent Variables Using Stata, $3^{\text {rd }}$ ed. Stata press.

Luttmer, E. F. P., \& Singhal, M. (2014). Tax Morale. Journal of Economic Perspectives. 28(4), 149-68. https://doi.org/10.1257/jep.28.4.149

Martinez-Vazquez, J. \& Torgler, B. (2009) The Evolution of Tax Morale in Modern Spain. Journal of Economic Issues. 43(1), 1-28. https://doi.org/10.2753/JEI0021-3624430101

Mickiewicz, T., Rebmann, A., \& Sauka, A. (2017). To Pay or Not to Pay? Business Owners' Tax Morale: Testing a Neo-Institutional Framework in a Transition Environment. Journal of Business Ethics. 1-19. https://doi.org/10.1007/s10551017-3623-2

Onu, D. (2016). Measuring Tax Compliance Attitudes: What Surveys Can Tell Us about Tax Compliance Behaviour, in J. Hasseldine (ed.) Advances in Taxation Vol.23, 173-190.

Pope, J. and Mohdali, R. (2010). The Role of Religiosity in Tax Morale and Tax Compliance. Australian Tax Forum. 25(4), 565-596.

Ranđelović, S. (2017). How to boost tax morale and tax compliance in Serbia. Journal of Business, Economics and Management - Ekonomika preduzeća. 65(1-2), 113-127.

Torgler, B. (2006). The importance of faith: Tax morale and religiosity. Journal of Economic Behavior and Organization. 61(1) 81-109. https://doi.org/10.1016/j.jebo.2004.10.007

Torgler, B. (2007). Tax compliance and tax morale: a theoretical and empirical analysis. Cheltenham, UK: Elgar. https://doi.org/10.4337/9781847207203

Torgler, B. (2012). Tax morale, Eastern Europe and the European enlargement. Communist and Post Communist Studies, 45(1), 11-25.

Torgler, B., Demir, I. C., Macintyre, A., \& Schaffner, M. (2007). Causes and Consequences of Tax Morale: An Empirical Investigation. Economic Analysis and Policy. 38(2), 313-339. https://doi.org/10.1016/S0313-5926(08)50023-3

Torgler, B., \& Schneider, F. (2007). What shapes attitudes toward paying taxes? Evidence from multicultural European countries. Social Science Quarterly, 88(2), 443-470. https://doi.org/10.1111/j.1540-6237.2007.00466.x

Williams, R. (2006). Generalized ordered logit/partial proportional odds models for ordinal dependent variables. Stata Journal, 6 (1), 58-82.

Williams, R. (2012). Using the margins command to estimate and interpret adjusted predictions and marginal effects. Stata Journal. 12(2), 308-331.

Williams, R. (2016). Understanding and interpreting generalized ordered logit models. Journal of Mathematical Sociology. 40(1), 7-20. https://doi.org/10.1080/0022250X.2015.1112384 